Article

\title{
Impact of Farmland Abandonment on Water Resources and Soil Conservation in Citrus Plantations in Eastern Spain
}

\author{
Artemi Cerdà ${ }^{1}\left(\mathbb{D}\right.$, Oren Ackermann $^{2}$, Enric Terol ${ }^{3}$ and Jesús Rodrigo-Comino ${ }^{4, *}$ \\ 1 Soil Erosion and Degradation Research Group, Department of Geography, Valencia University, Blasco \\ Ibàñez, 28, 46010 Valencia, Spain; artemio.cerda@uv.es \\ 2 Israel Heritage Department and the Department of Land of Israel Studies and Archaeology, Ariel University, \\ P.O.B. 3, Ariel 4070000, Israel; orenac@ariel.ac.il \\ 3 Department of Cartographic Engineering, Geodesy and Photogrammetry, Universitat Politècnica de \\ València, Camino de Vera, s/n, 46022 Valencia, Spain; eterol@cgf.upv.es \\ 4 Instituto de Geomorfología y Suelos, Department of Geography, University of Málaga, Edificio Ada Byron, \\ Ampliación del Campus de Teatinos, 29071 Málaga, Spain \\ * Correspondence: rodrigo-comino@uma.es or geo.jrc@gmail.com
}

Received: 28 March 2019; Accepted: 17 April 2019; Published: 19 April 2019

check for updates

\begin{abstract}
Due to the reduction in the prices of oranges on the market and social changes such as the ageing of the population, traditional orange plantation abandonment in the Mediterranean is taking place. Previous research on land abandonment impact on soil and water resources has focused on rainfed agriculture abandonment, but there is no research on irrigated land abandonment. In the Valencia Region-the largest producer of oranges in Europe-abandonment is resulting in a quick vegetation recovery and changes in soil properties, and then in water erosion. Therefore, we performed rainfall simulation experiments $\left(0.28 \mathrm{~m}^{2} ; 38.8 \mathrm{~mm} \mathrm{~h}^{-1}\right)$ to determine the soil losses in naveline orange plantations with different ages of abandonment $(1,2,3,5,7$ and 10 years of abandonment) which will allow for an understanding of the temporal changes in soil and water losses after abandonment. Moreover, these results were also compared with an active plantation (0). The results show that the soils of the active orange plantations have higher runoff discharges and higher erosion rates due to the use of herbicides than the plots after abandonment. Once the soil is abandoned for one year, the plant recovery reaches $33 \%$ of the cover and the erosion rate drops one order of magnitude. This is related to the delay in the runoff generation and the increase in infiltration rates. After 2, 3, 5, 7 and 10 years, the soil reduced bulk density, increase in organic matter, plant cover, and soil erosion rates were found negligible. We conclude that the abandonment of orange plantations reduces soil and water losses and can serve as a nature-based solution to restore the soil services, goods, and resources. The reduction in the soil losses was exponential (from $607.4 \mathrm{~g} \mathrm{~m}^{-2}$ in the active plot to $7.1 \mathrm{~g} \mathrm{~m}^{-2}$ in the 10-year abandoned one) but the water losses were linear (from 77.2 in active plantations till $12.8 \%$ in the 10 -year abandoned ones).
\end{abstract}

Keywords: agricultural land management; irrigated fields; erosion; abandonment; soil properties

\section{Introduction}

Citrus plantations are widespread due to the increase in the fruit demand around the world [1,2]. The traditional citrus production regions such as Valencia face a crisis due to production in other regions [3]. A social and economic change is taking place in traditional citrus production areas due to the ageing of the population, the competition of the large farms managed by companies, and social and economic changes [4]. The small size of traditional farms is also a key concern for the viability of 
production [5]. Citrus production in Valencia is facing technical modernization in large farms, with drip irrigation and highly mechanized systems where labor is reduced [6] but the soil and water losses are enhanced (Keesstra et al., 2019). In front, we have traditional small size farms, with flood irrigation and high labor costs that result in low income for the farmers. Moreover, in the Valencia region, the ageing of the farmers and the social changes (to be a farmer is not attractive for the new generation) and low income associated with farming results in farmland abandonment [7].

Land abandonment has been widely researched in the last 50 years $[8,9]$. This is a consequence of the changes in the economy of developed countries rather than triggered different drivers [10,11]. From an environmental point of view, abandonment results in an increase in the infiltration rates [12] due to vegetation recovery [13]. Soil erosion is also reduced by the effect of the vegetation cover and the recovery of organic matter [14].

The research carried out on recent land abandonment was done in rainfed land. This is due to the fact that the abandonment took place in rainfed land that did not evolve to irrigation [15]. The intensification of the agriculture contributed to increasing the land irrigated; meanwhile, the one that was less productive, usually the rainfed one, was abandoned. The research carried out on irrigated land is recent and focuses mainly on socioeconomic issues [16]. The abandonment provides ecosystems services such as carbon sequestration, water storage, soil properties, and seed bank fate improvements [17]. This response to land abandonment is widespread around the world [18-20].

Research on the abandonment of traditional irrigation farms was restricted until now to the historical, archaeological, and ecological approach [21-23]. There is no information about the changes in soil hydrology and soil erosion once the abandonment takes place in traditional flood irrigated land. This paper is the first approach to understand the effect of irrigated farmland abandonment on soil erosion and runoff discharge. Our main goal is to determine how the soil and water resources change once abandonment takes place and how to evolve along a decade with the use of plots in use or abandoned for 1, 2, 3, 5, 7 and 10 years.

\section{Materials and Methods}

\subsection{Study Area}

The research presented in this paper was carried out in the Canyoles River watershed, in the fluvial terraces (145 m a.s.l.) in the municipality of Canals (Valencia, Spain), a representative zone of the Mediterranean citrus plantation that was established along the 1960s. The farm properties are small in size in this region, and usually, all the farms are smaller than 1 ha and the average at the study site is $0.45 \mathrm{ha}$. The active field is flood irrigated and herbicide (Glyphosate) is applied any time the weeds germinate, which results in a bare soil surface. Once abandonment takes place there is a quick recovery of the vegetation. The climate is typically Mediterranean with a mean annual precipitation of $532 \mathrm{~mm}$ and a mean annual temperature of $16.2^{\circ} \mathrm{C}$. The soil is an Anthrosol [24] and the texture of the soil is clay-loam: $21 \%$ clay, $39 \%$ silt, and $40 \%$ sand. The planting pattern is $5 \mathrm{~m} \times 4 \mathrm{~m}$, the usual pattern for citrus in this agricultural area. The farm was flood-irrigated with freshwater from the Riu de Sants, which flows from the Massís del Caroig aquifer. The slope is negligible due to the land flattering and the effects of the floods on the fields. The soils are basic in $\mathrm{pH}$ (7.9). The observed soil profiles were very homogeneous as a consequence of tillage practices for centuries and land levelling. The study area was selected in the Pleistocene fluvial terrace of the Canyoles River (near the hamlet of Aiacor) and show 22\% gravel content. The irrigation system (Sèquia de Ranes) flows from the nearby Riu de Sants spring. Irrigation takes place every 2 weeks in the summer and does not take place once the fields are abandoned. The management up until the time of abandonment was similar in all plots: herbicide (Glyphosate (N-(phosphonomethyl)glycine) and inorganic fertilizers (NPK-nitrogen, phosphorus, and potassium $-0.8 \mathrm{Mg}$ ha-1 per year). Once the plots are abandoned, neither irrigation nor fertilization takes place. 


\subsection{Experimental Design}

The experimental design was based on the fact that the study area has suffered since 2000 a progressive abandonment due to the low income in such small parcels, the dropping of the prices of the oranges, and the ageing of the landowners. Then we selected a farm that was active and the neighbouring farms that had been abandoned for 1, 2, 3, 5, 7 and 10 years (Figure 1A). At each farm, we selected 10 representative $1-\mathrm{m}^{2}$ plot where sampling and simulated rainfall experiments on $0.28-\mathrm{m}^{2}$ plots were carried out (Figure 1B). All the plots have Citrus sinensis plantations with Naveline variety and "Carrizo" rootstock.
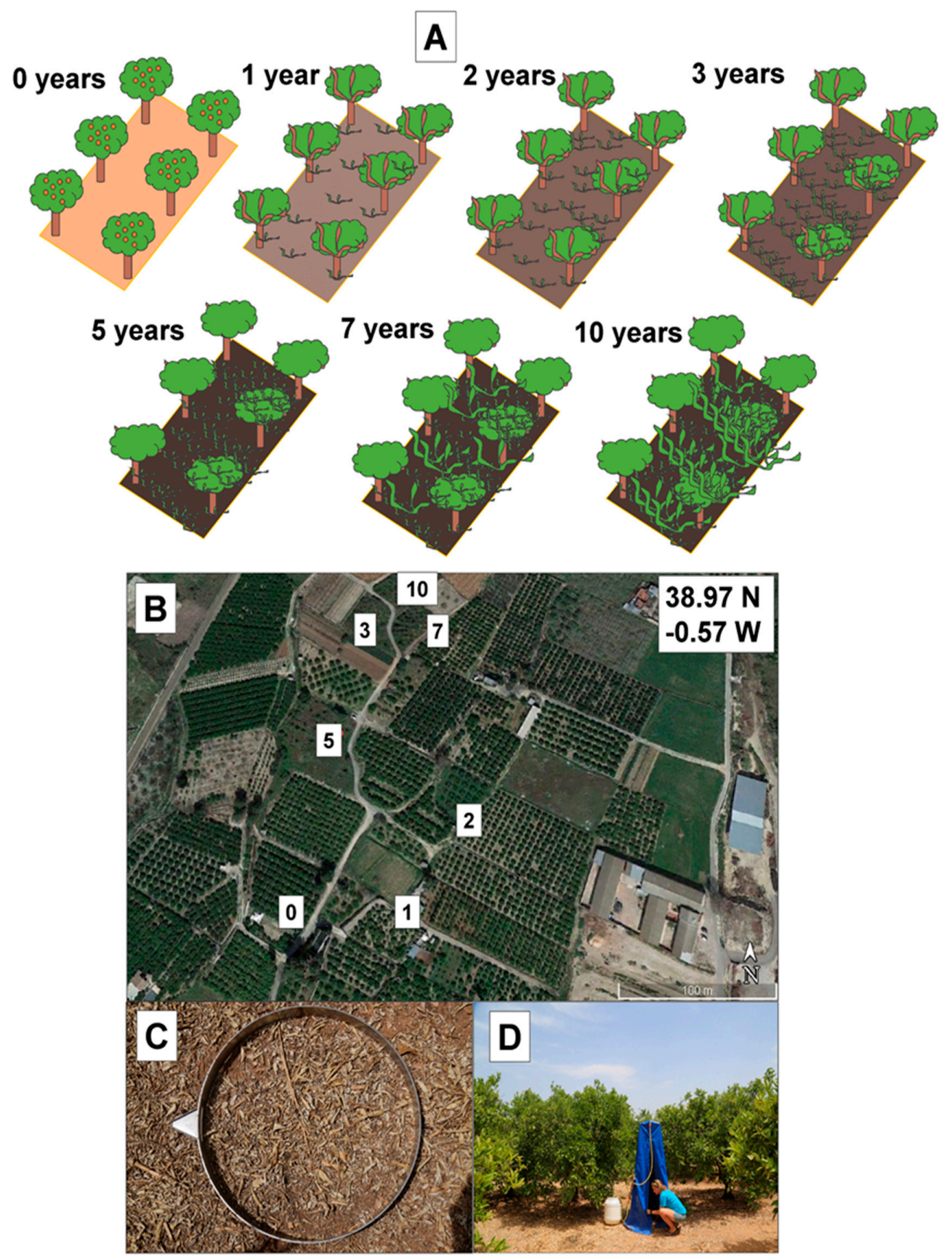

Figure 1. Scheme of the study plots (A), localization of the experimental fields (B), ring plot in the active farm (C), and field campaign (D). 


\subsection{Soil Sampling}

The seven experimental fields show different ages of abandonment. Age 0 is the active field with no weed cover due to the use of herbicides, and 1,2,3,5, 7, and 10 years are the fields that were abandoned along the last decade. The soil sampling took place in August 2014 during the Mediterranean summer drought. Ten soil samples were taken from the top $6 \mathrm{~cm}$ of the soil using a $100 \mathrm{~cm}^{3}$ steel cylinder. We measured gravimetric soil water content (SWC) and bulk density (BD). Moreover, soil samples were weighed, oven dried at $105^{\circ} \mathrm{C}$ during $24 \mathrm{~h}$, and weighed at room temperature to estimate organic matter by the dichromate method [25]. Also, grain size distribution was calculated by the pipette method. Vegetation cover, stones, and soil crusts were estimated using 100 pins evenly distributed in the rainfall simulation plot.

\subsection{Rainfall Simulation Experiments}

Seventy experiments (10 repetitions $\times 7$ plots) during $1 \mathrm{~h}$ for the active and $1,2,3,5,7$, and 10 years of abandonment were carried out at $38.8 \mathrm{~mm} \mathrm{~h}^{-1}$ rainfall intensity on the circular paired ring plot $\left(0.28 \mathrm{~m}^{2}\right.$; Figure $\left.1 \mathrm{C}, \mathrm{D}\right)$. These rainfall events are characterised by a return period around 2 years in the eastern Iberian Peninsula and have been used widely in rainfall simulation experiments [26]. All experiments were carried out when the soil moisture was low during the last week of July 2014 with no rainfall events to avoid variability among plots. Runoff was collected each 1-min interval and total water loss was calculated. Then, the runoff coefficient was obtained by means of the percentage of rainfall water flowing through the ring plot. In the laboratory, runoff samples were desiccated $\left(105^{\circ} \mathrm{C}\right.$, $24 \mathrm{~h})$ and soil loss was obtained based on the weight basis per area and time $\left(\mathrm{g} \mathrm{m}^{2} \mathrm{~h}^{-1}\right)$. Furthermore, it was also possible to quantify time to ponding (time required for $40 \%$ of the surface to be ponded; $\mathrm{Tp}, \mathrm{s})$, time to runoff initiation ( $\mathrm{Tr}, \mathrm{s})$, and time required by runoff to reach the outlet (Tro, s). Those parameters show how the runoff initiation takes place and how ponding is transformed into runoff and how the runoff reaches the runoff outlet.

\subsection{Statistical Analysis}

Descriptive statistics were calculated (mean, median, maximum, and minimum) and used for further statistical analysis. Soil properties were represented in linear graphs in order to show their evolutions during the studied period using Excel software (Windows, Redmond, Washington, DC, USA). The number of points used for each analysis corresponded to all measurements done at each location. Then, the hydrological response was represented as polar graphs dividing by intervals (natural breaks) the obtained results. Finally, soil erosion results were depicted in scatterplots using SigmaPlot 12.0 (Systat, Chicago, IL, USA). Statistical differences were evaluated performing an ANOVA one-way test to check the statistically significant differences among years of abandonment. If the normality test failed (Shapiro-Wilk), a Tukey test was conducted when the homogeneity variance fails (Levene's test). Finally, a Spearman rank correlation coefficient was carried out in order to assess the possible connection between environmental plot characteristics and soil erosion results.

\section{Results}

\subsection{Soil Properties}

The soils of the seven study sites affected by different times since abandonment show changes that can shed light into the evolution of the soil properties upon abandonment (Figure 2). Antecedent soil moisture is reduced from $14 \%$ to $5.1 \%$ in ten years of abandonment. Bulk density does not show significative changes after 1 year of abandonment (from 1.38 to $1.37 \mathrm{~g} \mathrm{~cm}^{-3}$ ), but after that, the values decrease to $1.15 \mathrm{~g} \mathrm{~cm}^{-3}$ in the tenth year of abandonment. On the contrary, organic matter and plant cover quickly increased after the abandonment, showing changes from 0.93 to $1.79 \%$ and from 1.1 to $90.3 \%$, respectively. The cover of rock fragments varies among plots, reaching the maximum values in 
the plots after 1, 2, and 3 years of abandonment. Finally, the development of soil crusts also shows a drastic decrease from the active plot $(83.4 \%)$ to the 10 years abandoned plot $(3.4 \%)$.
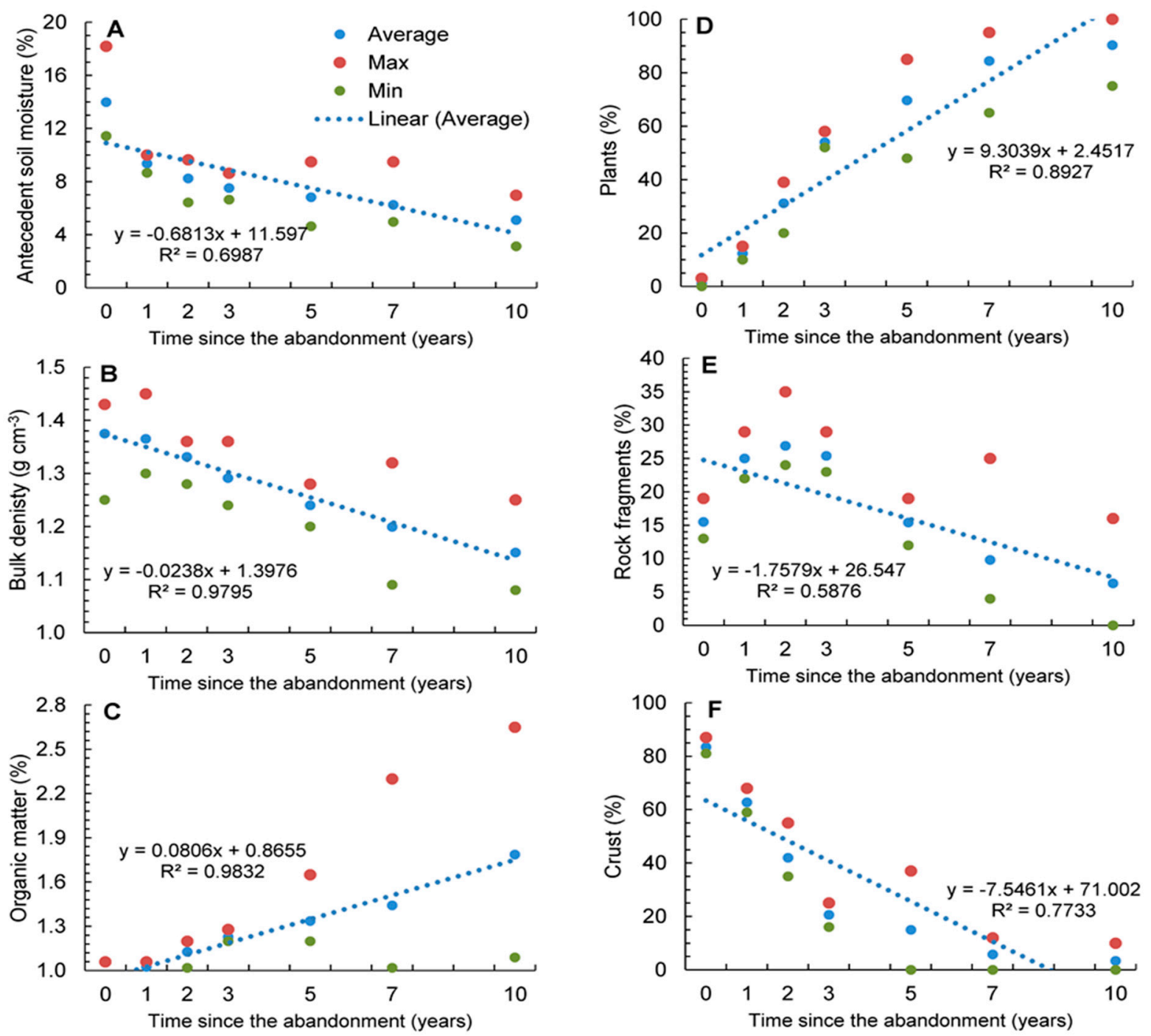

Figure 2. Variation of soil properties over different time periods since abandonment. (A) Antecentt soil moisture; (B); Bulk density; (C); Organic matter; (D); Plants; (E) Rock fragments; (F) Crust.

\subsection{Hydrological Response}

Figure 3 shows the time to ponding, time to runoff generation, and time to runoff in the outlet (seconds) represented in polar graphs. Table 1 shows the results of the Tukey test applied to all the seven study sites. The results show that among plots, there exists a clear statistically significant difference after the abandonment $(p<0.001)$. Time to ponding moves from 25.9 to 238.1 seconds, respectively, from the active plot to the 10 years abandoned one. Time to ponding was much delayed after seven years of abandonment. Runoff was generated after 47.2 seconds in the cultivated plot and after the runoff was delayed by 477.8 seconds. There was a clear trend that showed a progressive delay in the ponding and runoff initiation once the abandonment took place. Moreover, a clear variance among the 10 repetitions in each plot was also relevant, which could be affected by the uneven distribution of the plant recovery. The time to a runoff in the outlet was faster $(88.3 \mathrm{~s})$ in the active plot and delayed after the abandoned. The 10-year abandoned plot needed $917 \mathrm{~s}$ to achieve runoff at the outlet. 
a) Time to ponding (s)

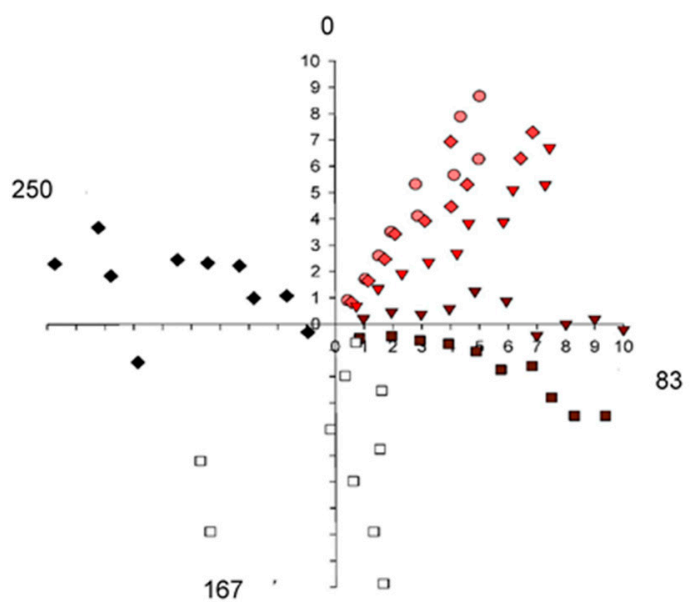

b) Time to runoff (s)

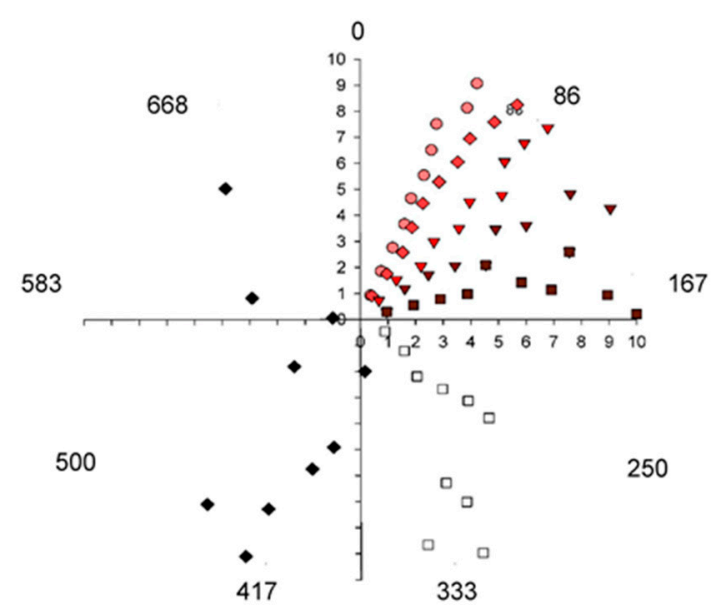

Time since the abandonment (years)

$\begin{array}{ll}\circ & 0 \\ \diamond & 1 \\ \nabla & 2 \\ \nabla & 3 \\ - & 5 \\ \square & 7 \\ - & 10\end{array}$

c) Time to runoff in outlet (s)

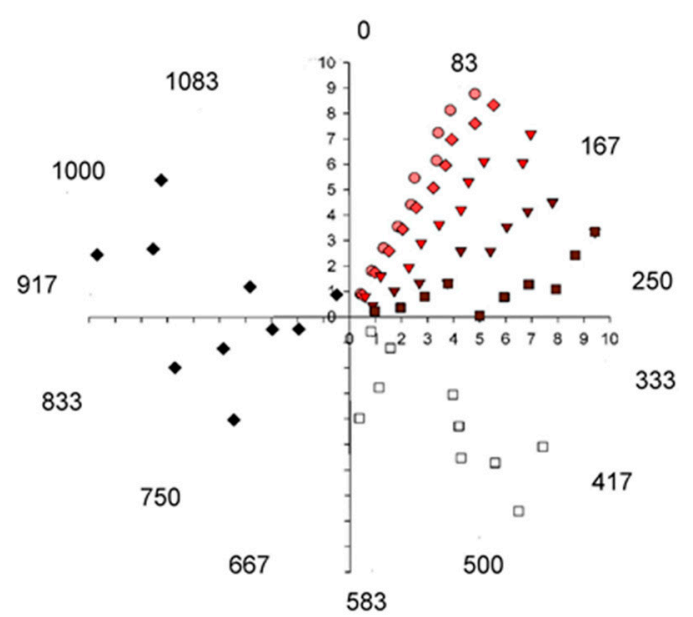

Figure 3. Hydrological response depending on the period of abandonment $\left(360^{\circ}=\right.$ range of values). 
Table 1. Statistical differences of hydrological responses and soil erosion results among periods of abandonment. Tp: time to ponding; Tr: time to runoff generation; Tro: time to runoff in outlet; Rc: runoff coefficient; SC: sediment concentration; SL: soil loss.

\begin{tabular}{|c|c|c|c|c|c|c|}
\hline Years & $\mathrm{Tp}$ & $\operatorname{Tr}$ & Tro & Rc & SL & SC \\
\hline 0 vs. 1 & $<0.001$ & $<0.001$ & $<0.001$ & 0.536 & 0.005 & $<0.001$ \\
\hline 0 vs. 2 & $<0.001$ & $<0.001$ & $<0.001$ & 0.007 & $<0.001$ & $<0.001$ \\
\hline 0 vs. 3 & $<0.001$ & $<0.001$ & $<0.001$ & $<0.001$ & $<0.001$ & $<0.001$ \\
\hline 0 vs. 5 & $<0.001$ & $<0.001$ & $<0.001$ & $<0.001$ & $<0.001$ & $<0.001$ \\
\hline 0 vs. 7 & $<0.001$ & $<0.001$ & $<0.001$ & $<0.001$ & $<0.001$ & $<0.001$ \\
\hline 0 vs. 10 & $<0.001$ & $<0.001$ & $<0.001$ & $<0.001$ & $<0.001$ & $<0.001$ \\
\hline 1 vs. 2 & $<0.001$ & $<0.001$ & $<0.001$ & 0.036 & $<0.001$ & 0.338 \\
\hline 1 vs. 3 & $<0.001$ & $<0.001$ & $<0.001$ & $<0.001$ & $<0.001$ & $<0.001$ \\
\hline 1 vs. 5 & $<0.001$ & $<0.001$ & $<0.001$ & $<0.001$ & $<0.001$ & $<0.001$ \\
\hline 1 vs. 7 & $<0.001$ & $<0.001$ & $<0.001$ & $<0.001$ & $<0.001$ & $<0.001$ \\
\hline 1 vs. 10 & $<0.001$ & $<0.001$ & $<0.001$ & $<0.001$ & $<0.001$ & $<0.001$ \\
\hline 2 vs. 3 & $<0.001$ & $<0.001$ & $<0.001$ & 0.205 & $<0.001$ & 0.002 \\
\hline 2 vs. 5 & $<0.001$ & $<0.001$ & $<0.001$ & 0.014 & $<0.001$ & $<0.001$ \\
\hline 2 vs. 7 & $<0.001$ & $<0.001$ & $<0.001$ & $<0.001$ & $<0.001$ & $<0.001$ \\
\hline 2 vs. 10 & $<0.001$ & $<0.001$ & $<0.001$ & $<0.001$ & $<0.001$ & $<0.001$ \\
\hline 3 vs. 5 & 0.002 & $<0.001$ & $<0.001$ & $<0.001$ & 0.002 & 0.048 \\
\hline 3 vs. 7 & $<0.001$ & $<0.001$ & $<0.001$ & $<0.001$ & $<0.001$ & 0.014 \\
\hline 3 vs. 10 & $<0.001$ & $<0.001$ & $<0.001$ & $<0.001$ & $<0.001$ & $<0.001$ \\
\hline 5 vs. 7 & $<0.001$ & $<0.001$ & $<0.001$ & $<0.001$ & $<0.001$ & 0.400 \\
\hline 5 vs. 10 & $<0.001$ & $<0.001$ & $<0.001$ & $<0.001$ & $<0.001$ & $<0.001$ \\
\hline 7 vs. 10 & $<0.001$ & $<0.001$ & $<0.001$ & 0.005 & $<0.001$ & 0.003 \\
\hline
\end{tabular}

\subsection{Runoff, Soil Loss, and Sediment Concentration}

In Figure 4, runoff coefficient, sediment concentration, and soil loss are depicted in box plots. The runoff coefficient shows the highest rates in the active plot, reaching average values of $77.2 \%$ of the rainfall, with maximum ones of $96.3 \%$. On the contrary, in the other plots, the average runoff coefficient descends to $71.8,51,42.3,32.3,22.3$, and $12.8 \%$ for 1, 2, 3, 5, 7- and 10-years of abandonment, respectively. The highest variability can be observed after the second year of abandonment. In Table 1, it is possible to observe values with non-statistically significant differences in runoff coefficients between $0-1$ year and 2-3-years after abandonment. Sediment concentration also shows a drastic decrease from the active plot to the 10-year abandoned field, obtaining values from 14.7 (maximum values of $20.4 \mathrm{~g} \mathrm{~L}^{-1}$ ) to $1 \mathrm{~g} \mathrm{~L}^{-1}$ (maximum values of $1.02 \mathrm{~g} \mathrm{~L}^{-1}$ ). Table 2 shows that all the plots have significant differences in this parameter. The soil loss parameter also shows a decrease: from 607.4 (active plot), 271.4 (1 year), 150.3 (2 years), 62.8 (3 years), 33.46 (5 years), 19.7 (7 years) till $7.1 \mathrm{~g} \mathrm{~m}^{-2}$ (10 years). Table 1 shows that between 1-2 years and 5-7 years of abandonment, no differences can be observed, but there are differences in other years. 

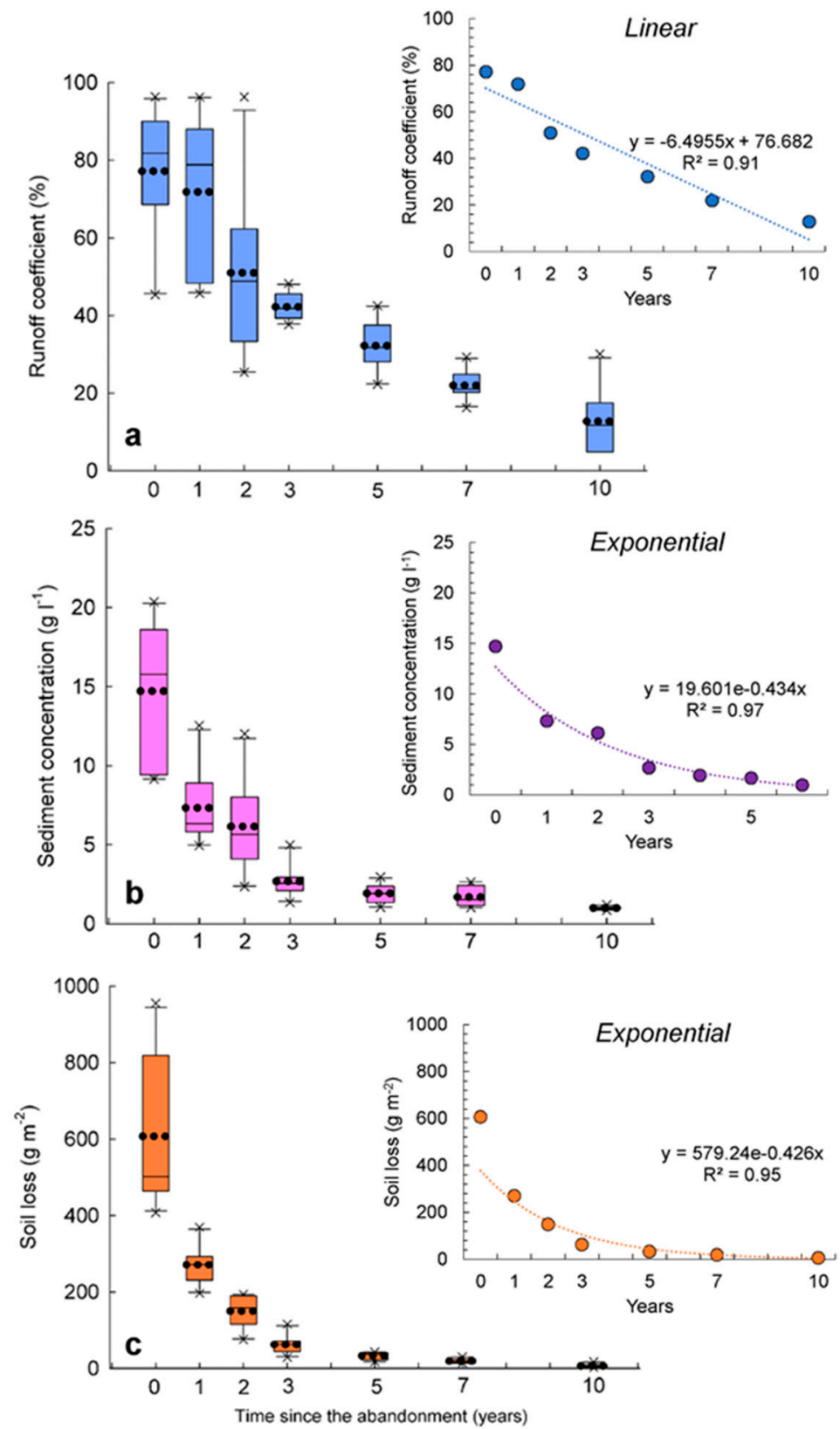

Figure 4. Evolution of the runoff coefficient, sediment concentration, and soil loss along the abandonment time from active plantations to 10-years old abandonment. Dotted line: average $(n=10)$. (a) Runoff coefficient; (b) Sediment concentration; (c) Soil loss.

Table 2. Spearman rank coefficient between environmental factors, hydrological responses, and soil erosion. SM: antecedent soil moisture; BD: bulk density; OM: organic matter; Plants: plant cover; Rock: rock fragment cover; Crust: soil crust; Tp: time to ponding; Tr: time to runoff generation; Tro: time to runoff in outlet; Rc: runoff coefficient; SC: sediment concentration; SL: soil loss.

\begin{tabular}{ccccccc}
\hline Variables & Tp & Tr & Tro & Rc & SC & SL \\
\hline SM & -0.84 & -0.84 & -0.85 & 0.77 & 0.80 & 0.77 \\
BD & -0.85 & -0.86 & -0.85 & 0.80 & 0.81 & 0.75 \\
OM & 0.82 & 0.83 & 0.83 & -0.77 & -0.76 & -0.70 \\
Plants & 0.95 & 0.95 & 0.95 & -0.87 & -0.88 & -0.84 \\
Rock & -0.56 & -0.54 & -0.54 & 0.59 & 0.49 & 0.49 \\
Crust & -0.93 & -0.93 & -0.93 & 0.85 & 0.85 & 0.81 \\
\hline
\end{tabular}


In Table 2, it can be observed that only the rock fragment cover does not show a high correlation with the hydrological responses and soil erosion results. On the other hand, the highest Spearman rank coefficient values were obtained between the development of a high plant cover and the positive relationship with $\operatorname{Tp}(0.95), \operatorname{Tr}(0.95)$, and Tro (0.95), and the negative one with $\operatorname{Rc}(-0.87)$, SSC $(-0.88)$, and SL (-0.84). Moreover, high positive correlations were observed with the OM contents. On the contrary, higher values of antecedent soil moisture, bulk density, and soil crust were highly correlated with Tp, Tro, and Tro, and Rc, Sc, and SL.

\section{Discussion}

The use of developing countries as food producers, an increase in agricultural productivity, and the use of fossil fuels that reduce the need for animal traction and then for food production for them has reduced the need to use part of the agriculture land $[27,28]$. This abandonment has environmental consequences such as changes in water resources, vegetation cover and floristic composition, fauna, and soil properties, which will affect also earth system functioning as they will control the biogeochemical cycles [29-33]. Agriculture land abandonment is not a new issue from a social, economic, and environmental point of view [34], but what is new is the agriculture technology that was developed after War World II which has led to the widespread abandonment and contributed to the restoration of the vegetation and fauna and the reduction in the soil losses in many parts of the world $[35,36]$.

The research on the impact of abandonment of agriculture on environmental issues focused on rainfed land [37], as the irrigated land used to be intensified [38,39]. Our research contributes to new data generated in flood irrigated land that is being abandoned due to socioeconomic changes. The findings demonstrated that the soils are able to recover plant cover and soil organic matter once abandoned as other authors demonstrated in other types of agricultural land [17,40]. The changes in plant cover will affect fauna such as has been demonstrated by other colleagues [41-43] and soil properties. The non-utilisation of irrigation has generated soils which contain a lower amount of water (antecedent soil moisture), which could affect some other pedological processes such as organic matter development or aggregate stability $[44,45]$. Considering these changes, the diminution of soil bulk density is also a relevant factor that could affect soil erosion activation [46]. As Bienes et al. [47] observed in Central Spain, significant changes in bulk density used to appear after the abandonment took place due to plant recolonization because of the root development and organic matter increase. In our study area, weeds, grass, and small shrubs were distributed in little patches that directly affect these pedological changes.

The plant cover (weeds) was mainly Paretaria Judaica, Conyza sumatrensis, Amarathus hibridus L., and Chenopodium album. Once abandoned, the cover of Paretaria Judaica increased, but other plants appeared such as Avena fatua, Asparragus sp., and Rubus ulmifolius that finally became the dominant species.

Once the land was abandoned, we also observed a significant difference in the rock fragment cover. Possibly, the surface wash and tillage could remove the fine material and more rock fragments were visible on the surface $[48,49]$. However, after the third year of abandonment, the vegetation cover reduced neither the crust nor the rock fragments in the soil surface. This would also be an interesting topic for research in the future because of its direct impacts on soil erosion processes and biogeological systems.

Our research confirms that after the abandonment there was a sudden reduction in overland flows that is shown in delayed ponding and runoff generation. This means that more water infiltrates. However, our measurements also demonstrate that the amount of water flowing through and on the soil is also reduced after the abandonment takes place. This can be due to the reduction in the effective rainfall as the interception increases with the growth of the vegetation and the development of a litter layer [50,51]. The impact of the litter was researched by the pioneer study of Facelli and Pickett [52] and found that litter plays a key role in the water balance. Rainfall interception in abandoned fields is related to the vegetation recovery, and the higher the biomass means a lower the net precipitation on the soil [53]. 
The loss of water reaching the soil after the abandonment of land changes the hydrological cycle, such as Hou et al. [54] found in the Loess hillslopes in China, Šraj et al. [50] in Slovenia, and Otero et al. [55] in Catalonia (Spain), where a loss of stream biodiversity and water availability was found. Those findings are highlighted by García-Ruiz and Lana-Renault [13] along with their review on the hydrological and erosive consequences of farmland abandonment in Europe. The impact of abandonment shows less water availability and more water used by the vegetation. This results in a river discharge reduction such as was demonstrated in the Central Spanish Pyrenees by Beguería et al. [56] or in Slovenia where the Dragonja River reduced the sediment delivery due to the loss of the runoff discharge as a consequence of the natural afforestation [57]. The use of water by the vegetation (transpiration) also resulted in the loss of water available by plants such as Moreira et al. [58] found in the Amazon on abandoned pastures, Rambousková et al. [59] in the abandoned fields in the Bohemian Karst, and Farrick and Price [60] in the Sphagnum restoration in peatlands.

Our research at the Canals municipality demonstrated that the reduction in the water yield was efficient as a consequence of the abandonment (from $77.2 \%$ in the active orange plantation to $12.8 \%$ in the 10-years abandoned plots), but the reduction shows a linear correlation (0.91; Figure 4a). However, for the sediment concentration and soil loss, the reduction followed a negative exponential trend with an adjustment of 0.97 and 0.95 , respectively (Figure $4 b, c$ ). This trend in the reduction of soil and water losses were also found in previous literature. Ruecker et al. [61]; Koulouri and Giourga [62], and Lesschen et al. [63] found this trend in abandoned Mediterranean terraces, Cerdà [12] in southeastern Spain in a semi-arid landscape, Liu et al. [64] in the Loess Plateau, and Arnáez et al. [65] in the La Rioja region, wherein the Camero Viejo district they found that abandonment controlled the soil erosion rates and landscape evolution. Land abandonment is a recurrent topic in the Mediterranean, and Portuguese examples confirm our findings here: control of soil losses by vegetation recovery [66].

Abandonment could be seen as a nature-based solution such as the use of straw in forest fire affected land [66,67] to the high erosion rates found in agricultural land [68], and could be used as a strategy to balance the carbon cycle [69] and rehabilitate the soils under the millennia-old use of agriculture [70]. The research carried out at the Canals Municipality shows that abandonment could be positive from an environmental point of view, but there is also the risk of a forest fire as the vegetation could be very flammable during the Mediterranean summer drought [71]. Thus, the next essential step of research is to find the optimal management of the abandoned orchards, and maybe it can be used as a recreation area for nearby urban citizens [72]. This could be a successful solution in the Mediterranean where agriculture land abandonment in the last decade also takes place in the surroundings of city areas due to the economic crisis [69] and for which similar responses have been shown in other developed countries [73]. How urban changes occur is related in one way to the environmental conditions [74] but also to the cultural impact of humans [75].

Once the fields are abandoned, the vegetation recovery takes places as a mosaic of plants and this response results in an increase in the spatial variability such as other authors found along climatological gradients [76]. We found this increase in the spatial distribution due to the formation of tussocks, or bare and plant covered patches, which is a clear factor in soil erosion, but with more intensity after the second year of abandonment [77]. Our findings are based on a local survey and should be used to supply basic information to develop proper models of water balance and soil erosion [78] that will shed light onto the effect of other management systems such as organic farming, land abandonment or cover crops and mulches $[79,80]$.

\section{Conclusions}

Citrus plantation abandonment results in a recovery of the vegetation cover and soil organic matter, and a reduction in the soil bulk density drought and soil moisture. Plant recovery is the key factor that determined a linear reduction in the runoff discharge (from 72 till $13 \%$ of the rainfall) over ten years of abandonment. The soil losses dropped from $607.4 \mathrm{~g} \mathrm{~m}^{-2}$ in the active plot to $7.1 \mathrm{~g} \mathrm{~m}^{-2}$ in the 10 years after abandonment took place. We conclude that the abandonment of orange plantations 
could reduce soil and water losses if there is a proper plant recovery, which allows it to be considered as a potential nature-based solution to restore the soil services, goods, and resources.

Author Contributions: A.C.: investigation, methodology, data acquisition, data preparation, writing, supervising. O.A.: data analysis, data preparation, writing. E.T.: investigation, methodology, data acquisition, data preparation, writing. J.R.C.: data analysis, data preparation, methodology, writing.

Funding: This paper is part of the results of research projects GL2008-02879/BTE, LEDDRA 243857 and RECARE-FP7 (ENV.2013.6.2-4).

Acknowledgments: During the field work the music of Raimon "Diguem no" was our inspiration and during the data analysis and writing the histories of "El Comandante Lara". Moreover, we want to thank the guest editors and reviewers for their careful review process.

Conflicts of Interest: The authors declare no conflict of interest.

\section{References}

1. Regmi, A. Changing Structure of Global Food Consumption and Trade; Department of Agriculture, Agriculture and Trade Report, Market and Trade Economics Division, Economic Research Service: Washington, DC, USA, 2001; ISBN 978-1-4289-4047-5.

2. Stefler, D.; Pikhart, H.; Kubinova, R.; Pajak, A.; Stepaniak, U.; Malyutina, S.; Simonova, G.; Peasey, A.; Marmot, M.G.; Bobak, M. Fruit and vegetable consumption and mortality in Eastern Europe: Longitudinal results from the Health, Alcohol and Psychosocial Factors in Eastern Europe study. Eur. J. Prev. Cardiol. 2016, 23, 493-501. [CrossRef] [PubMed]

3. Alford, M.; Barrientos, S.; Visser, M. Multi-scalar Labour Agency in Global Production Networks: Contestation and Crisis in the South African Fruit Sector. Dev. Chang. 2017, 48, 721-745. [CrossRef]

4. Cerdà, A.; Rodrigo-Comino, J.; Giménez-Morera, A.; Novara, A.; Pulido, M.; Kapović-Solomun, M.; Keesstra, S.D. Policies can help to apply successful strategies to control soil and water losses. The case of chipped pruned branches (CPB) in Mediterranean citrus plantations. Land Use Policy 2018, 75, 734-745. [CrossRef]

5. Ortega-Reig, M.; Sanchis-Ibor, C.; Palau-Salvador, G.; García-Mollá, M.; Avellá-Reus, L. Institutional and management implications of drip irrigation introduction in collective irrigation systems in Spain. Agric. Water Manag. 2017, 187, 164-172. [CrossRef]

6. Cerdà, A.; Rodrigo-Comino, J.; Giménez-Morera, A.; Keesstra, S.D. An economic, perception and biophysical approach to the use of oat straw as mulch in Mediterranean rainfed agriculture land. Ecol. Eng. 2017, 108, 162-171. [CrossRef]

7. Keesstra, S.D.; Rodrigo-Comino, J.; Novara, A.; Giménez-Morera, A.; Pulido, M.; Di Prima, S.; Cerdà, A. Straw mulch as a sustainable solution to decrease runoff and erosion in glyphosate-treated clementine plantations in Eastern Spain. An assessment using rainfall simulation experiments. CATENA 2019, 174, 95-103. [CrossRef]

8. Levers, C.; Schneider, M.; Prishchepov, A.V.; Estel, S.; Kuemmerle, T. Spatial variation in determinants of agricultural land abandonment in Europe. Sci. Total Environ. 2018, 644, 95-111. [CrossRef]

9. Kou, M.; Jiao, J.; Yin, Q.; Wang, N.; Wang, Z.; Li, Y.; Yu, W.; Wei, Y.; Yan, F.; Cao, B. Successional trajectory over 10 years of vegetation restoration of abandoned slope croplands in the Hill-Gully region of the Loess Plateau. Land Degrad. Develop. 2016, 27, 919-932. [CrossRef]

10. Ito, J.; Nishikori, M.; Toyoshi, M.; Feuer, H.N. The contribution of land exchange institutions and markets in countering farmland abandonment in Japan. Land Use Policy 2016, 57, 582-593. [CrossRef]

11. Lasanta, T.; Arnáez, J.; Pascual, N.; Ruiz-Flaño, P.; Errea, M.P.; Lana-Renault, N. Space-time process and drivers of land abandonment in Europe. CATENA 2017, 149, 810-823. [CrossRef]

12. Cerdà, A. Soil erosion after land abandonment in a semiarid environment of southeastern Spain. Arid Soil Res. Rehabil. 1997, 11, 163-176. [CrossRef]

13. García-Ruiz, J.M.; Lana-Renault, N. Hydrological and erosive consequences of farmland abandonment in Europe, with special reference to the Mediterranean region-A review. Agric. Ecosyst. Environ. 2011, 140, 317-338. [CrossRef] 
14. Cerdà, A.; Rodrigo-Comino, J.; Novara, A.; Brevik, E.C.; Vaezi, A.R.; Pulido, M.; Giménez-Morera, A.; Keesstra, S.D. Long-term impact of rainfed agricultural land abandonment on soil erosion in the Western Mediterranean basin. Prog. Phys. Geogr. Earth Environ. 2018, 42, 202-219. [CrossRef]

15. Rodrigo-Comino, J.; Martínez-Hernández, C.; Iserloh, T.; Cerdà, A. Contrasted Impact of Land Abandonment on Soil Erosion in Mediterranean Agriculture Fields. Pedosphere 2018, 28, 617-631. [CrossRef]

16. Vidal-Macua, J.J.; Ninyerola, M.; Zabala, A.; Domingo-Marimon, C.; Gonzalez-Guerrero, O.; Pons, X. Environmental and socioeconomic factors of abandonment of rainfed and irrigated crops in northeast Spain. Appl. Geogr. 2018, 90, 155-174. [CrossRef]

17. Alonso-Sarría, F.; Martínez-Hernández, C.; Romero-Díaz, A.; Cánovas-García, F.; Gomariz-Castillo, F. Main environmental features leading to recent land abandonment in Murcia Region (Southeast Spain). Land Degrad. Dev. 2016, 27, 654-670. [CrossRef]

18. Gispert, M.; Pardini, G.; Colldecarrera, M.; Emran, M.; Doni, S. Water erosion and soil properties patterns along selected rainfall events in cultivated and abandoned terraced fields under renaturalisation. CATENA 2017, 155, 114-126. [CrossRef]

19. Horel, Á.; Tóth, E.; Gelybó, G.; Kása, I.; Bakacsi, Z.; Farkas, C. Effects of Land Use and Management on Soil Hydraulic Properties. Open Geosci. 2015, 7, 742-754. [CrossRef]

20. Yu, W.J.; Jiao, J.Y.; Chen, Y.; Wang, D.L.; Wang, N.; Zhao, H.K. Seed Removal due to Overland Flow on Abandoned Slopes in the Chinese Hilly Gullied Loess Plateau Region. Land Degrad. Dev. 2017, 28, $274-282$. [CrossRef]

21. Löw, F.; Fliemann, E.; Abdullaev, I.; Conrad, C.; Lamers, J.P.A. Mapping abandoned agricultural land in Kyzyl-Orda, Kazakhstan using satellite remote sensing. Appl. Geogr. 2015, 62, 377-390. [CrossRef]

22. Lightfoot, D.R. Syrian qanat Romani: History, ecology, abandonment. J. Arid Environ. 1996, 33, 321-336. [CrossRef]

23. Verheyen, K.; Bossuyt, B.; Hermy, M.; Tack, G. The land use history (1278-1990) of a mixed hardwood forest in western Belgium and its relationship with chemical soil characteristics. J. Biogeogr. 1999, 26, 1115-1128. [CrossRef]

24. IUSS Working Group WRB. World Reference Base for Soil Resources 2014; World Soil Resources Report; FAO: Rome, Italy, 2014.

25. Walkley, A.; Black, I.A. An examination of Degtjareff method for determining soil organic matter and a proposed modification of the chromic acid titration method. Soil Sci. 1934, 37, 29-37. [CrossRef]

26. Iserloh, T.; Fister, W.; Seeger, M.; Willger, H.; Ries, J.B. A small portable rainfall simulator for reproducible experiments on soil erosion. Soil Tillage Res. 2012, 124, 131-137. [CrossRef]

27. Grădinaru, S.R.; Kienast, F.; Psomas, A. Using multi-seasonal Landsat imagery for rapid identification of abandoned land in areas affected by urban sprawl. Ecol. Indic. 2019, 96, 79-86. [CrossRef]

28. Basualdo, M.; Huykman, N.; Volante, J.N.; Paruelo, J.M.; Piñeiro, G. Lost forever? Ecosystem functional changes occurring after agricultural abandonment and forest recovery in the semiarid Chaco forests. Sci. Total Environ. 2019, 650, 1537-1546. [CrossRef] [PubMed]

29. Yin, H.; Prishchepov, A.V.; Kuemmerle, T.; Bleyhl, B.; Buchner, J.; Radeloff, V.C. Mapping agricultural land abandonment from spatial and temporal segmentation of Landsat time series. Remote Sens. Environ. 2018, 210, 12-24. [CrossRef]

30. Yin, H.; Butsic, V.; Buchner, J.; Kuemmerle, T.; Prishchepov, A.V.; Baumann, M.; Bragina, E.V.; Sayadyan, H.; Radeloff, V.C. Agricultural abandonment and re-cultivation during and after the Chechen Wars in the northern Caucasus. Glob. Environ. Chang. 2019, 55, 149-159. [CrossRef]

31. Baba, Y.G.; Tanaka, K.; Kusumoto, Y. Changes in spider diversity and community structure along abandonment and vegetation succession in rice paddy ecosystems. Ecol. Eng. 2019, 127, 235-244. [CrossRef]

32. Klee, R.J.; Zimmerman, K.I.; Daneshgar, P.P. Community Succession after Cranberry Bog Abandonment in the New Jersey Pinelands. Wetlands 2019, 39. [CrossRef]

33. Agnoletti, M.; Errico, A.; Santoro, A.; Dani, A.; Preti, F. Terraced Landscapes and Hydrogeological Risk. Effects of Land Abandonment in Cinque Terre (Italy) during Severe Rainfall Events. Sustainability 2019, 11, 235. [CrossRef]

34. Fredh, E.D.; Lagerås, P.; Mazier, F.; Björkman, L.; Lindbladh, M.; Broström, A. Farm establishment, abandonment and agricultural practices during the last 1300 years: A case study from southern Sweden based on pollen records and the LOVE model. Veget. Hist. Archaeobot. 2019, 39. [CrossRef] 
35. Lasanta, T.; Nadal-Romero, E.; Arnáez, J. Managing abandoned farmland to control the impact of re-vegetation on the environment. The state of the art in Europe. Environ. Sci. Policy 2015, 52, 99-109. [CrossRef]

36. Bell, S.; Alves, S.; Silveirinha de Oliveira, E.; Zuin, A. Migration and land use change in Europe: A review. Living Rev. Landsc. Res. 2010, 4. [CrossRef]

37. Rodrigo-Comino, J.; Senciales, J.M.; Sillero-Medina, J.A.; Gyasi-Agyei, Y.; Ruiz-Sinoga, J.D.; Ries, J.B. Analysis of Weather-Type-Induced Soil Erosion in Cultivated and Poorly Managed Abandoned Sloping Vineyards in the Axarquía Region (Málaga, Spain). Air Soil Water Res. 2019, 12, 1178622119839403. [CrossRef]

38. Carter, D.L. Furrow Irrigation Erosion Lowers Soil Productivity. J. Irrig. Drain. Eng. 1993, 119, 964-974. [CrossRef]

39. Al-Ghobari, H.M.; Dewidar, A.Z. Integrating deficit irrigation into surface and subsurface drip irrigation as a strategy to save water in arid regions. Agric. Water Manag. 2018, 209, 55-61. [CrossRef]

40. Cammeraat, E.L.H.; Cerdà, A.; Imeson, A.C. Ecohydrological adaptation of soils following land abandonment in a semi-arid environment. Ecohydrology 2010, 3, 421-430. [CrossRef]

41. Osawa, T.; Kohyama, K.; Mitsuhashi, H. Trade-off relationship between modern agriculture and biodiversity: Heavy consolidation work has a long-term negative impact on plant species diversity. Land Use Policy 2016, 54, 78-84. [CrossRef]

42. Hannula, S.E.; Morriën, E.; de Hollander, M.; van der Putten, W.H.; van Veen, J.A.; de Boer, W. Shifts in rhizosphere fungal community during secondary succession following abandonment from agriculture. ISME J. 2017, 11, 2294-2304. [CrossRef]

43. Cavani, L.; Manici, L.M.; Caputo, F.; Peruzzi, E.; Ciavatta, C. Ecological restoration of a copper polluted vineyard: Long-term impact of farmland abandonment on soil bio-chemical properties and microbial communities. J. Environ. Manag. 2016, 182, 37-47. [CrossRef] [PubMed]

44. He, B.; Wang, H.; Huang, L.; Liu, J.; Chen, Z. A new indicator of ecosystem water use efficiency based on surface soil moisture retrieved from remote sensing. Ecol. Indic. 2017, 75, 10-16. [CrossRef]

45. Ramos, M.C.; Martínez-Casasnovas, J.A. Impact of land levelling on soil moisture and runoff variability in vineyards under different rainfall distributions in a Mediterranean climate and its influence on crop productivity. J. Hydrol. 2006, 321, 131-146. [CrossRef]

46. Al-Shammary, A.A.G.; Kouzani, A.Z.; Kaynak, A.; Khoo, S.Y.; Norton, M.; Gates, W. Soil Bulk Density Estimation Methods: A Review. Pedosphere 2018, 28, 581-596. [CrossRef]

47. Bienes, R.; Marques, M.J.; Sastre, B.; García-Díaz, A.; Ruiz-Colmenero, M. Eleven years after shrub revegetation in semiarid eroded soils. Influence in soil properties. Geoderma 2016, 273, 106-114. [CrossRef]

48. Jomaa, S.; Barry, D.A.; Brovelli, A.; Heng, B.C.P.; Sander, G.C.; Parlange, J.Y.; Rose, C.W. Rain splash soil erosion estimation in the presence of rock fragments. CATENA 2012, 92, 38-48. [CrossRef]

49. Poesen, J.; Van Wesemael, B.; Govers, G.; Martinez-Fernandez, J.; Desmet, P.; Vandaele, K.; Quine, T.; Degraer, G. Patterns of rock fragment cover generated by tillage erosion. Geomorphology 1997, 18, 183-197. [CrossRef]

50. Šraj, M.; Brilly, M.; Mikoš, M. Rainfall interception by two deciduous Mediterranean forests of contrasting stature in Slovenia. Agric. For. Meteorol. 2008, 148, 121-134. [CrossRef]

51. Leuning, R.; Condon, A.G.; Dunin, F.X.; Zegelin, S.; Denmead, O.T. Rainfall interception and evaporation from soil below a wheat canopy. Agric. For. Meteorol. 1994, 67, 221-238. [CrossRef]

52. Facelli, J.M.; Pickett, S.T.A. Plant Litter: Light Interception and Effects on an Old-Field Plant Community. Ecology 1991, 72, 1024-1031. [CrossRef]

53. Llorens, J.; Gil, E.; Llop, J.; Queraltó, M. Georeferenced LiDAR 3D vine plantation map generation. Sensors 2011, 11, 6237-6256. [CrossRef] [PubMed]

54. Hou, J.; Fu, B.; Liu, Y.; Lu, N.; Gao, G.; Zhou, J. Ecological and hydrological response of farmlands abandoned for different lengths of time: Evidence from the Loess Hill Slope of China. Glob. Planet. Chang. 2014, 113, 59-67. [CrossRef]

55. Otero, I.; Boada, M.; Badia, A.; Pla, E.; Vayreda, J.; Sabaté, S.; Gracia, C.A.; Peñuelas, J. Loss of water availability and stream biodiversity under land abandonment and climate change in a Mediterranean catchment (Olzinelles, NE Spain). Land Use Policy 2011, 28, 207-218. [CrossRef]

56. Beguería, S.; López-Moreno, J.I.; Lorente, A.; Seeger, M.; García-Ruiz, J.M. Assessing the effect of climate oscillations and land-use changes on streamflow in the central Spanish Pyrenees. Ambio 2003, 32, $283-286$. [CrossRef] [PubMed] 
57. Keesstra, S.D.; Bruijnzeel, L.A.; Huissteden, J. Meso-scale catchment sediment budgets: Combining field surveys and modeling in the Dragonja catchment, southwest Slovenia. Earth Surf. Process. Landf. 2009, 34, 1547-1561. [CrossRef]

58. Moreira, M.Z.; Sternberg, S.L.; Nepstad, D.C. Vertical patterns of soil water uptake by plants in a primary forest and an abandoned pasture in the eastern Amazon: An isotopic approach. Plant Soil 2000, 222, 95-107. [CrossRef]

59. Rambousková, H. Water dynamics of some abandoned fields of the Bohemian Karst. Folia Geobot. Phytotax. 1981, 16, 133. [CrossRef]

60. Farrick, K.K.; Price, J.S. Ericaceous shrubs on abandoned block-cut peatlands: Implications for soil water availability and Sphagnum restoration. Ecohydrology 2009, 2, 530-540. [CrossRef]

61. Ruecker, G.; Schad, T.; Alcubilla, M.N.; Ferrer, C. Natural regeneration of degraded soils and site changes on abandoned agricultural terraces in Mediterranean Spain. Land Degrad. Dev. 1998, 9, 179-188. [CrossRef]

62. Koulouri, M.; Giourga, C. Land abandonment and slope gradient as key factors of soil erosion in Mediterranean terraced lands. CATENA 2007, 69, 274-281. [CrossRef]

63. Lesschen, J.P.; Cammeraat, L.H.; Nieman, T. Erosion and terrace failure due to agricultural land abandonment in a semi-arid environment. Earth Surf. Process. Landf. 2008, 33, 1574-1584. [CrossRef]

64. Liu, Y.; Tao, Y.; Wan, K.Y.; Zhang, G.S.; Liu, D.B.; Xiong, G.Y.; Chen, F. Runoff and nutrient losses in citrus orchards on sloping land subjected to different surface mulching practices in the Danjiangkou Reservoir area of China. Agric. Water Manag. 2012, 110, 34-40. [CrossRef]

65. Arnaez, J.; Lasanta, T.; Errea, M.P.; Ortigosa, L. Land abandonment, landscape evolution, and soil erosion in a Spanish Mediterranean mountain region: The case of Camero Viejo. Land Degrad. Dev. 2011, 22, 537-550. [CrossRef]

66. Nunes, A.N.; Coelho, C.O.A.; de Almeida, A.C.; Figueiredo, A. Soil erosion and hydrological response to land abandonment in a central inland area of Portugal. Land Degrad. Dev. 2010, 21, 260-273. [CrossRef]

67. Smetanová, A.; Follain, S.; David, M.; Ciampalini, R.; Raclot, D.; Crabit, A.; Le Bissonnais, Y. Landscaping compromises for land degradation neutrality: The case of soil erosion in a Mediterranean agricultural landscape. J. Environ. Manag. 2019, 235, 282-292. [CrossRef] [PubMed]

68. Lucas-Borja, M.E.; Zema, D.A.; Carrà, B.G.; Cerdà, A.; Plaza-Alvarez, P.A.; Cózar, J.S.; Gonzalez-Romero, J.; Moya, D.; de las Heras, J. Short-term changes in infiltration between straw mulched and non-mulched soils after wildfire in Mediterranean forest ecosystems. Ecol. Eng. 2018, 122, 27-31. [CrossRef]

69. Tang, S.; Guo, J.; Li, S.; Li, J.; Xie, S.; Zhai, X.; Wang, C.; Zhang, Y.; Wang, K. Synthesis of soil carbon losses in response to conversion of grassland to agriculture land. Soil Tillage Res. 2019, 185, 29-35. [CrossRef]

70. Xie, Y.; Lin, H.; Ye, Y.; Ren, X. Changes in soil erosion in cropland in northeastern China over the past 300 years. CATENA 2019, 176, 410-418. [CrossRef]

71. García-Llamas, P.; Suárez-Seoane, S.; Taboada, A.; Fernández-Manso, A.; Quintano, C.; Fernández-García, V.; Fernández-Guisuraga, J.M.; Marcos, E.; Calvo, L. Environmental drivers of fire severity in extreme fire events that affect Mediterranean pine forest ecosystems. For. Ecol. Manag. 2019, 433, 24-32. [CrossRef]

72. Trukhachev, A. Methodology for Evaluating the Rural Tourism Potentials: A Tool to Ensure Sustainable Development of Rural Settlements. Sustainability 2015, 7, 3052-3070. [CrossRef]

73. Grimm, N.B.; Faeth, S.H.; Golubiewski, N.E.; Redman, C.L.; Wu, J.; Bai, X.; Briggs, J.M. Global Change and the Ecology of Cities. Science 2008, 319, 756-760. [CrossRef]

74. Ackermann, O.; Zhevelev, H.M.; Svoray, T. Agricultural systems and terrace pattern distribution and preservation along climatic gradient: From sub-humid mediterranean to arid conditions. Quat. Int. 2019, 502, 319-326. [CrossRef]

75. Ackermann, O.; Maeir, A.M.; Frumin, S.S.; Svoray, T.; Weiss, E.; Zhevelev, H.M.; Horwitz, L.K. The Paleo-Anthropocene and the Genesis of the Current Landscape of Israel. J. Landsc. Ecol. 2017, 10, 109-140. [CrossRef]

76. Ackermann, O.; Zhevelev, H.M.; Svoray, T. Sarcopoterium spinosum from mosaic structure to matrix structure: Impact of calcrete (Nari) on vegetation in a Mediterranean semi-arid landscape. CATENA 2013, 101, 79-91. [CrossRef]

77. Cerdà, A. The effect of patchy distribution of Stipa tenacissima L. on runoff and erosion. J. Arid Environ. 1997, 36, 37-51. [CrossRef] 
78. Ibáñez, J.; Contador, J.F.L.; Schnabel, S.; Fernández, M.P.; Valderrama, J.M. A model-based integrated assessment of land degradation by water erosion in a valuable Spanish rangeland. Environ. Model. Softw. 2014, 55, 201-213. [CrossRef]

79. Di Prima, S.; Rodrigo-comino, J.; Novara, A.; Iovino, M.; Pirastru, M.; Keesstra, S.; Cerdà, A. Soil Physical Quality of Citrus Orchards Under Tillage, Herbicide, and Organic Managements. Pedosphere 2018, 28, $463-477$. [CrossRef]

80. Kasirajan, S.; Ngouajio, M. Polyethylene and biodegradable mulches for agricultural applications: A review. Agron. Sustain. Dev. 2012, 32, 501-529. [CrossRef]

(C) 2019 by the authors. Licensee MDPI, Basel, Switzerland. This article is an open access article distributed under the terms and conditions of the Creative Commons Attribution (CC BY) license (http://creativecommons.org/licenses/by/4.0/). 